\title{
Contemporary art from a city at war: The case of Gaza (Palestine)
}

\author{
Marion Slitine \\ EHESS (Ecole des Hautes Etudes en Sciences Sociales), Paris, France
}

\section{A R T I C L E INFO}

\section{Keywords:}

Contemporary art

Visual arts

Gaza

Palestine

War

Urban crisis

Engagement

\begin{abstract}
A B S T R A C T
When the Hamas organisation won territorial elections in 2006, the Gaza Strip has been experiencing a humanitarian crisis due to the ensuing Israeli embargo. Despite the resulting political and economic turmoil, Gaza has witnessed great vitality in its artistic scene. Most Palestinian artists actually come from Gaza, and a significant number of them have recently managed to gain international visibility. Besides the capacity of art to provide alternative visual narratives of a besieged city, art in this context is a tool that participates in construction of the city itself. This article aims to explore the interaction between art production and the backdrop of war within an urban landscape. It bears witness to the great artistic vitality of the Gazan people and moreover highlights Gaza's emerging cultural scene and the role increasingly played by the media and social networks, in contrast with the simplistic images often being conveyed. Based on both semi-structured interviews held with Gazan artists and participant observation in the local visual arts scene, this article seeks to shed light on the relationship between art and city in a context of urban crisis, through recognising Gaza's place as a Palestinian urban centre. Central to the issue of Palestinian national question and to potential breakthroughs in the Israeli-Palestinian conflict, Gaza is also relevant to understanding a number of challenges facing Arab and Muslim societies. Examining Gaza's art production in this specific context is crucial to comprehending how art participates in building a new city, beyond the media's narrowly stereotyped images.
\end{abstract}

\section{Introduction}

At first glance, art and war make an unlikely pair: the former creates while the latter destroys. Yet their encounter has nourished the history of painting. In the works of Spanish artists from Francisco de Goya (1746-1828) to Pablo Picasso (1881-1973), or among German painters such as Otto Dix (1891-1969) and Georges Grosz (1893-1959), war stands out as one of the main themes of modern and contemporary art. In February 2015, a few months after Israel's military assault on Gaza in the summer of 2014, the British street artist Banksy decided to cross Rafah - the border between Egypt and the Gaza Strip - through the tunnels. His intention was to cover Gaza's walls with his renowned graffiti, as a denunciation of the city's destruction: "Gaza is often described as 'the world's largest open air prison' because no one is allowed to enter or leave. But that seems a bit unfair to prisons - they don't have their electricity and drinking water cut off randomly almost every day". ${ }^{1}$ On one of the ravaged walls, the street artist wrote: "If we wash our hands of the conflict between the powerful and the powerless, we side with the powerful - we don't remain neutral". In so doing, Banksy wanted to change the stereotyped image of Gaza that the mainstream media reflects, as have many other artists living through this situation of permanent war.

Besides the capacity of art to provide alternative visual narratives of a city at war, I argue in this article that art can be used as a participatory tool to in the making of the city itself. The aim herein is to explore the interaction between art production and the context of hostilities in an urban setting. A testimonial will be offered to the Gazan people's great artistic vitality, as found in other contexts where "the exacerbation of closure happens through the proliferation of walls". ${ }^{2}$ As Novosseloff and Neisse wrote, the closure of a frontier can re-activate cultural production and transform its meaning (as is the case for example at the US/Mexico border). Along these lines, the present article will therefore highlight Gaza's emerging cultural scene and the role being increasingly played by the media and social networks, in contrast with the simplistic images often conveyed. Through their images and words, these artists deliver messages that resonate beyond borders; they reveal their native land in another light, despite the constrained conditions of creation and circulation in effect. In a nutshell, the artists are seeking to have their voices heard beyond the borders that confine them, in portraying their native land through another lens. Based on semi-structured interviews held with Gazan artists ${ }^{3}$ and participant observations within the local visual arts scene, the article will expose the relationship between art and city against a backdrop of urban crisis.

A small piece of land amidst a tormented region, the Gaza Strip is an essential part of Palestine's future, ${ }^{4}$ endowed with its own social-cultural dynamics and resistance strategies. Central to the issue of Palestinian national question and to potential breakthroughs in the Israeli-Palestinian conflict, Gaza is also relevant to understanding a number of challenges facing Arab and Muslim so- 
cieties. Examining Gaza's art production in this specific context is crucial to comprehending how art participates in building a new city, beyond the distorted vision all too often being spread.

\section{2. "Urbicide" and besieged culture}

Under Israeli blockade ${ }^{5}$ and having weathered four wars since $2006,{ }^{6}$ Gaza now appears to be left to its own fate. It is even subject to "urbicide", a term applied by Stephen Graham to describe the deliberate wrecking or killing of a city. ${ }^{7}$ This term could be defined as the act of destroying buildings and cities that do not contain any military targets:

"Urbicide is rather an act that is supposed to affect the very life of the population in such a way that war cannot be ignored by anybody and must be experienced on a daily basis by a nation's civilians. Urbicide had thus become a scientific, surgical, military operation in architecture that either simply murders a civilian population by the means of architecture, or practically and symbolically destroys the organisational and cultural aspects of the city in a biopolitical attack on a population."

The extreme vulnerability of this minuscule strip of land $\left(360 \mathrm{~km}^{2}\right.$ with one of the highest population densities in the world) does not a priori encourage artistic creation, and being an artist in Gaza is far from an easy vocation. Yet despite a context so unfavourable to practicing art, the local visual arts scene (photography, painting, sculpture, drawing, engraving, installations) has been vibrant since 2000. Through the use of heterogeneous aesthetics, young artists - all those mentioned in this article are younger than forty - are able to document, denounce and transgress their local reality by means of art.

For nearly 2 million inhabitants, entering and exiting the Gaza strip is practically impossible and depends on a system of permits ${ }^{9}$ created and run by Israeli authorities, thus drastically limiting the circulation of people and culture. Gaza artists, though often invited abroad, are rarely authorised to leave the territory. ${ }^{10}$ The blockade has also adversely affected the supply of materials necessary for artistic creation. Until 2015, only one shop in all of Gaza was selling acrylic colours, and at a price of 10 dollars a tube (double that of 2007, when Israel imposed import restrictions in response to Hamas' victory in the 2006 legislative elections and the organisation's takeover of Gaza in June 2007).

1 http://www.telegraph.co.uk/culture/banksy/11436286/

Banksy-in-Gaza-Street-artist-goes-undercover-in-the-Strip.htm

2 Novosseloff, A. \& Neisse, F., Des murs entre les hommes, Paris, La Documentation française, 2007, p. 102.

3 All artists' quotes have been extracted from interviews conducted in Gaza between 2013 and 2015. They have been translated from Arabic by the author. The participant observations have been specially compiled via a professional mission as Cultural Officer at the French Institute in Jerusalem $(2011$ - 2012).

4 "Gaza [is] an inseparable part of Palestine's past, present and future", Tawil-Souri, Helga, in "Larger-than-life-Gaza", in Tawil-Souri Helga \& Matar Dina (dir.), Gaza as metaphor, Hurst \& Company London, London, 2016, p. 11.

5 Hamas won the January 2006 elections, defeating Fatah which had run the territory for the previous ten years. Palestinian President Mahmoud Abbas was obliged to cede control of the government in Gaza to Hamas leader Ismail Haniyeh. However, conflict between the two camps persisted. In June 2007, Hamas controlled the government in Gaza, while Fatah was in control of the West Bank. Since that time, the two territories have been administered by rival factions. In October 2017, Hamas and Fatah signed a reconciliation deal in Cairo, after Egyptian-brokered negotiations.

6 These were 'Summer Rains' (28 June 2006), 'Cast Lead' (27 December 2008-18 January 2009), 'Pillar of Defense' (14-21 November 2012), and 'Protective Edge' (8 July-26 August 2014). The most recent operation caused the deaths of more than two thousand Palestinians.

7 Graham, Stephen, "Introduction to Urbicide: The Killing of Cities?", in Theory \& Event, January 2007: https://www.researchgate.net/publication/240967991.

8 Lambert, Leopold, Weaponised Architecture: The Impossibility of Innocence. Barcelona, Spain: DPR-Barcelona, 2013.

9 The Gazan population has been regularly prevented from moving since the beginning of the Israeli occupation in 1967. However, it was only in June 1989 during the First Intifada that exit permits were actually restricted, with Israel allowing only humanitarian aid and commercial dealings with the Strip. In January 1991, the Israeli authorities suspended all exit permits during the Gulf War, and all such permits were revoked altogether after 2000 and the Second Intifada, meaning that the entire territory was hemmed in (www.ochaopt.org).

10 Schneider, Mirjam, Rapport de l'Union Européenne, Preparatory action Culture in EU
Above and beyond the blockade, moral barriers within Palestinian society itself burden artists' lives and activities: censorship of contemporary artists is frequent in Gaza. At the graduation ceremony of the Al-Aqsa Fine Arts College in 2009, the expressionist canvasses of twin brothers Arab and Tarzan Nasser ${ }^{11}$ were destroyed during the night because "it spoke about women, about love and not just about the sufferings of the Palestinian people". ${ }^{12}$ Images of - nude and unveiled - women in fine arts textbooks have been erased while the painting of live models has been prohibited. In 2010, the Department of Fine Arts was closed by Hamas due to its gender diversity and liberality, which were perceived to be excessive. ${ }^{13}$ Several cases of artists incarcerated and imprisoned by local authorities for producing an "art of transgression" have been recorded. An employee of the (Hamas) Ministry of Culture justified this authoritarian policy of controlling local cultural forms: "One can speak about everything, but in compliance with our values, with our religion. We don't want any nudity, no pornographic scenes [rap music is considered to belong to this category]. It's about not going beyond the ways outlined by our traditions" ${ }^{14}$ For the time being, "making contemporary art" in Gaza can be considered as an act of subversion and protest against the powers in place, as stated by the artist Mohammed Hawajri in 2014: "Practicing this kind of art [contemporary art] in Gaza is dangerous. Some say that it is haram [a sin] but we resist, we continue". ${ }^{15}$

As Jean-François Legrain wrote, Hamas' proactive policy in the media field can be explained as the result of exacerbating tensions with the Fatah Party that "reinforced Hamas' drive to endow a media apparatus with as much diversity and efficiency as possible, in a context of active marginalization at either the local, regional or international level" (Legrain, 2009). Cultural activities benefit from even a minimal amount of government support, which is basically limited to the production of official art. While the Palestinian Ministry of Culture has withdrawn from overseeing culture (the Ministry of Culture budget represented just $0.003 \%$ of the total territorial budget in $2013^{16}$ ), this situation has been reversed since 2010 by international organisations, civil society and, to a lesser extent, the private sector. Despite some investments by Hamas authorities in cultural activities, such as the organisation of collective exhibitions at the local level, support for art collectives and the creation of art centres (e.g. Asda City ${ }^{17}$ ), the cultural offering in Gaza remains confined to networks dependent on limited and discontinuous international aid. In 2014, Gaza only counted a few art galleries, no active art museums and zero cinemas (as all them were shut down by radical groups back in the 1980 's ${ }^{18}$ ). In such a precarious cultural climate, the French Institute of Gaza, ${ }^{19}$ created in 1982, has played a key role in supporting local artistic creation, reinforced by the fact that France is the only country to still have a cultural and consular outpost in the Gaza Strip. Moreover, a few art galleries, organised around collectives of artists, also shape the Gazan cultural world. The Gaza Strip is one of the few

11 Coming from a modest background, Ahmad and Mohammed Abu Nasser (their real names) were born in Gaza in 1988 in the Jabalia Refugee Camp. After graduating from the Al-Aqsa University Faculty of Fine Arts, they were forced to leave Gaza in 2011 due to threats against them from the Hamas government, travelling first to Jordan and then to France, where they have been living since 2015 .

12 Interview with Arab \& Tarzan Nasser, Amman, January 2013.

13 Interview with Mohammed Musallam (Artist and Art History professor at Al-Aqsa University), March 2013.

14 Interview with Atef Askul, Gaza, June 2014.

15 Interview with Mohammed Hawajri, Gaza, February 2013.

16 Funding for the PLO from the international community fell with the First Intifada (See Culture in the EU's External Relations, Palestine Country Report, November 2013).

17 Asda City, for the promotion of cinema in Gaza, was created in 2007 by the Interior Minister, Fathi Hammad (Legrain, 2009).

18 Ghoul, Asma, "The Death of Cinema in Gaza", in Al-Monitor, February 6, 2013: http: //www.al-monitor.com/pulse/originals/2013/02/cinema-gaza-demise.html; see also the film "Gaza $36 \mathrm{~mm}$ " by Khalil Mozaien on the destruction of the cinematographic industry in the 1980 's by a number of Salafist groups.

19 The IFG is affiliated with the French Consulate in Jerusalem and since the beginning of the current decade has assumed the role previously played by the French Cultural Centre (FCC) set up in 1982 in premises belonging to Gaza's Young Men's Christian Association (YMCA). This is the only foreign cultural centre operating in Gaza today after the British Council was forced to close in 2006 
places in Palestine where after the 2000's, artist collectives working locally to promote contemporary art have begun to emerge. The "Eltiqa for Contemporary Art" and "Shababik, Windows for Contemporary Art" galleries, created in 2002 and 2009 respectively, are both particularly active and well connected to international art networks. ${ }^{20}$ The young artists making up the Eltiqa Group for Contemporary Art, the first collective of its kind and still one of the most influential, wanted to 'create a modern and contemporary art movement in Palestine'.${ }^{21}$ According to the French Cultural Center, two years after founding the collective, 'these young artists, who regularly travel abroad, have brought a breath of fresh air to Gaza by working in synergy and transforming their common studio into a place where individual practices are coupled with a collective impulse.'22 All of them were born in the 1970's in Gaza, with most being self-taught. They all emphasise their reluctance to embrace the training provided at Al-Aqsa University, describing it as 'too academic.' These artists remain more focused on the art market than their elders; they take part in the (still rare) auctions held in Gaza or the West Bank, ${ }^{23}$ and the website they launched collaboratively features a gallery section that includes works for sale. They know the venues where their works need to be exhibited to receive legitimacy, as well as key players in the art world (curators) and international contemporary art events. The collectives are also behind various exhibitions, both collective and individual, and in 2016 they set up spaces where contemporary art could be discussed both in Gaza and throughout Palestine. ${ }^{24}$ To a certain extent, men and women are able to mix freely in these collectives, as opposed to what occurs in other environments in Gaza, and the impression is given that the visual arts are not gender-biased (Fadda, 2008). ${ }^{25}$

Other artists' collectives, with nationalist and sometimes Islamic ideological profiles (such as "Roots Art" or the "Paletta Group for Art Palestine"26), were also created during these years. These groups organise exhibitions, workshops and meetings that frame the calendar of Gaza's cultural program. It is interesting to note that despite the local context, these cultural activities, at the collective level, are paradoxically quite frequent in Gaza [in comparison, for example, with the West Bank], and the number of collective exhibitions is higher here than elsewhere in Palestine. ${ }^{27}$ In Gaza, a growing number of artists have formed clusters, supported by the 2003 opening of a Fine Arts Department (at Al-Aqsa University), that train scores of youth every year in the field of plastic arts or art education. Last but not least, between 1998 and 2011, the number of cultural facilities in Gaza rose from 24 to 66, ranking it as the top Palestinian city. ${ }^{28}$ In 2012, there were 69 cultural centres in Gaza, vs. 59 in Ramallah and 56 in Jerusalem. The number of exhibitions held at the Gaza centres is higher than that held anywhere else (69 a year held in Gaza in 2012, vs. 29 in Ramallah and 3 in Jerusalem). Along with Ramallah, Gaza today is para-

20 The Eltiqa Collective (translatable as 'Meeting') was set up in Gaza in 2002 by Raed Issa, Mohamed Abusal, Mohammed Hawajri, Dena Matar, Mohammed Dabous, Suheil Salem and Abdel Raouf Ajouri. Shababik ('Windows') was founded in 2009 by Shareef Sarhan, Basel Maqosi and Majed Shala. See www.eltiqa.com and www.artwfg.ps.

21 Collective interview with the Eltiqa Group in Gaza (20 February 2013).

22 Draft mission statement, French Cultural Center archives, 2004. Consulted in June 2014

23 The first major auctions were held in 2002 and organised by UNDP (http://www. undp.ps/en/newsroom/pressreleasespdf/2005/8eb.pdf). The Jerusalem Gallery's Palestinian Art Court-Al Hoash has since held auctions on an annual basis (http:// english.pnn.ps/2016/05/27/

al-hoash-opens-up-its-arms-for-a-new-generation-of-palestinian-artists/).

24 See in particular, ?iwārāt al-fann al-khā?sa [Individual Dialogues on Art] created at the beginning of 2017: https://www.facebook.com/ \%D8\%AD\%D9\%88\%D8\%A7\%D8\%B1\%D8\%A7\%D8\%AA-\%D8\%A7\%D9\%84\%D9\%81\%D9\%86

25 Of the forty Gazan artists who responded to a questionnaire with 100 artists (held in January 2917), a third were women.

26 Roots Art: www.facebook.com/profile.php?id=100004840099220\&fref $=$ ts; Paletta Group for Art Palestine: www.facebook.com/pages/Paleta-Group-for-art-Palestine/ 193694954117426 ? fref $=$ ts.

27 Report by the Palestinian Central Bureau of Statistics (PCBS) on the "Activities in Cultural Centres Operating in Palestine by Region/Governorate and Type, 2014": http:// pcbs.gov.ps/Portals/_Rainbow/Documents/cult-2014-02e.htm.

28 According to the Palestinian Central Bureau of Statistics (PCBS), a 'cultural centre' doxically one of the most active cultural centres across the Occupied Palestinian Territories. Gaza thus appears as the heart of the Palestinian art scene and a laboratory for art and experimentation.

\section{New practices and "Jîl Oslo": an art of emergency}

Despite the precarious conditions in which their work is being produced, Gazan artists perceive art as a privileged space of expression, in which the local traditions of academic painting merge with contemporary aesthetics. In relying on techniques learned during their academic training at the Fine Arts Department in Gaza, local creators have long produced an art strongly connected to the collective nationalist imaginary and to salient episodes of local history, as dominated by representations of refugee camps, war and occupation. To engage with these themes, painting remains the privileged medium, and a highly figurative, narrative and symbolical pictorial tradition prevails. The iconography is particularly codified, with symbolical elements establishing the rhythm of compositions: the Dome of the Rock, the key of return, the olive tree, the keffiyeh and the Palestinian flag are among the visual icons found in these artworks and promoted as the expression of a collective nationalist memory.

Some artists however are reinterpreting this pictorial tradition. Such is the case of Dina Matar ${ }^{29}$ [Fig. 1], a young Al-Aqsa University alumnus who likewise depicts the reality of her local context but does so using a contemporary vocabulary. Her lively chromatic palette is combined with a cubist and surrealistic style inspired by Joan Miró (1893-1983) and Pablo Picasso in order to, in her words: "give a touch of hope to the context despite its degradation". 30

Others young artists favour an aesthetics closer to the codes of international contemporary art, enabled by the use of new technologies and the globalisation of art markets. Consequently, new media including video art, digital art and especially digital photography, which is frequently preferred by professional artists and amateurs alike, are readily found. These media are particularly fashionable thanks to their primary function of documenting, whether in art or photojournalism, war through images. Such is the case of Eman Mohammed, ${ }^{31}$ who had a work purchased by the British Museum Collection in 2013 [Fig. 2].

An inventory of this mosaic of media used in Gaza would not be complete without noting the increased use over the past ten years of installation art, which is tremendously popular among artists connected to the international art world. With his installation $A$ Metro in Gaza [Fig. 3], Mohammed Abusal, ${ }^{32}$ one of the founders of the Eltiqa Group for Contemporary Art, proposed a dreamy surrealistic vision of Gaza's local situation following his artistic residency at the Cité Internationale des Arts in Paris. Starting from the ironic observation of local populations' expertise in tunnel-building, he imagines a metro running in Gaza. Through a faithful reconstitution of Paris Metro sig-

29 Born in 1985, Dina Matar studied Fine Arts at Al-Aqsa University, from which she graduated in 2007. Her individual exhibition, Melody of Flowers, was displayed in the West Bank and Jerusalem in 2014 through the cultural network of the Institut Français de Jérusalem. Ms Matar's works were also shown in Doha and Abu Dhabi between 2012 and 2014. She has taken part in several collective exhibitions and was awarded an artist residency at the Cité Internationale des Arts de Paris in 2012.

30 Interview with Dina Matar, Gaza, February 2013.

31 Born in 1987, Eman Mohammed is a female photojournalist based in Gaza City and holds a Bachelor's degree from the Islamic University of Gaza in journalism and public relations. She was nominated for the Joop Swart Masterclass - World press photo 2009 award. Her photography has been featured in several prominent international media publications. Moreover, she has worked as a freelance photojournalist with several organisations, including the World Bank, Save the Children, UNFPA and MAP. http:// www.ted.com/talks/eman mohammed the courage to tell a hidden story.

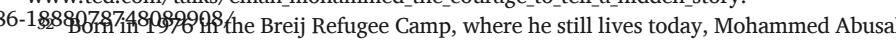
graduated from the Islamic University of Gaza in Accounting and from the Macromedia Digital University in Graphic Design. He works full-time as an artist, complementing his activities from time to time as a freelance designer for private companies. He has been awarded various residencies outside Gaza (Darat Al-Funun in Amman in 2000; the Cité des Arts in Paris in 2011; and the Fondation Camargo in Cassis in 2016). Moreover, his work has been exhibited in various European museums, including the Institut du Monde Arabe in Paris and the Imperial War Museum in London. He is one of Gaza's few artists to be represented by a gallery (the Zawiyeh Gallery in Ramallah). In 2000, he was among the founders of the Eltiqa Gallery, one of two dedicated to contemporary art in Gaza. A Metro in Gaza went on tour across the Palestinian Territories and received significant 


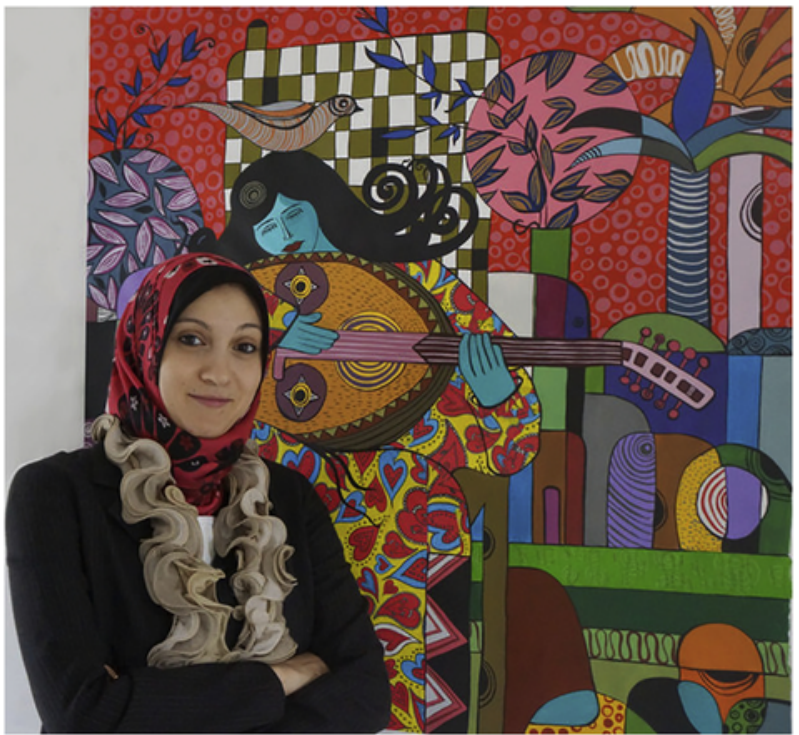

Fig. 1. Dina Matar, Contrary to what women like, Oil on canvas, 2011, () Courtesy of the artist.

nage, he crosses the city carrying an " $\mathrm{M}$ " and gathers testimonies from passers-by. Subsequently, he imagines an RER (suburban Paris rail) line connecting the various cities of the fragmented Palestinian territories (Jerusalem, West Bank and Gaza).

This artwork more generally echoes new practices being massively developed in the public space (mural paintings, graffiti, street art). In reality, these "new territories of art" 33 are not all that new since graffiti began in Gaza during the first Intifada in $1987,{ }^{34}$ when the Gaza Strip was devoid of Palestinian television, radio or newspapers: the messages spread on the walls became an important means of communication. Over the years, all political factions have inspired their own graffiti artists, hence the practice of murals (jidariyyat) has been predominant in the Gazan visual arts scene. During the second Intifada, this practice developed further, and graffiti became a visual tool to reinvent the "subjectivity of the resistance" and help communicate and spread messages of political and social protest, far from the censorship of traditional media. The "Arab Spring" eventually led to the widespread expansion of public space art. ${ }^{35}$

In 2013, the artist Mohammed Musallam ${ }^{36}$ launched a project entitled "Art in the public space" [Fig.4] that produces artworks from various environmental wastes degrading nature in Gaza. These works are exhibited outdoors to reach a larger audience as a means of "beautifying the external visually blighted areas". ${ }^{37}$ Mohammed Musallam has thus collected recycling materials (stoppers of plastic bottles, old CDs, wheels transformed into public benches or swings) and distributed the art project in various locations across Gaza, including: "Al-Ma'amunia Elementary School run by UNRWA, Al-Aqsa University, Gaza Municipal Park, the largest and oldest park in the city, 'Pleasing Childhood Institution' managed by the Gaza Municipality, the French Institute in Gaza, considered the most influential international cultural centre in Gaza, Al-Wadih Petrol Station in the Northern Gaza Strip. These projects contribute to raising

33 Lextrait, Fabrice and Kahn, Frédéric (dir.), Nouveaux territoires de l'art. Montreuil: Sujet, 2005.

34 Gröndhal, Mia, Gaza Graffiti: Messages of Love and Politics, The American University in Cairo Press, Cairo, 2009.

35 See the film by May Odeh, 2013, Art in the street, MOCAtv, 4'45": https://www. youtube. $\mathrm{com} /$ watch $\mathrm{t}=2 \& \mathrm{v}=2 \mathrm{TUivH} 2 \mathrm{oSAo}$.

36 Born in 1974 in Gaza, Mohammed Musallam is a visual artist. An Art History Professor at the University of Al-Aqsa, he received a Ph.D. in Visual Arts from the University of Helwan in Cairo in 2016. His thesis focused on the Gazan visual arts scene. His artwork ranges from abstract painting to video art, political installations and photography.

37 Preface by Nemer Alqiq (Head of the Department of Fine Arts, Al-Aqsa University), Catalogue of Mohammed Musallam, "Art in the Public Space", Afac, 2013. visual awareness through sampling artworks that are being exhibited for the first time in the public space in Gaza, while increasing awareness of many environmental issues.". 38

This artwork is relevant to what Helga Tawil-Souri wrote in Gaza as a metaphor:

“There is no 'proper time' to brush your teeth, because you do what you can when you can and where you can. Because in Gaza, you have to improvise [...] In Gaza nothing goes to waste, people 'make productive use of the available', thus revealing the 'implicit vitality".' ${ }^{39}$

In this context however, we are far from the "creative city" that Florida ${ }^{40}$ was describing when stating that artistic activities in public spaces could have the effect of making towns, cities and regions more attractive and/or enhancing the factors underpinning the existing economic fabric. In Gaza under siege, it is impossible for art to serve as an urban development tool, but rather simply a tool to beautify the city and, as shown below, a tool to showcase the "urban fabric". ${ }^{41}$

Despite the imprisonment and wars that Gaza has suffered over the past decade, artists still attempt to overcome obstacles imposed by the blockade. More specifically, they have used and redirected the use of makeshift materials in their work, as exemplified by the readymades of Marcel Duchamp (1887-1968): new "ways of doing"42 have emerged; unprecedented ways of creating are invented, as was the case in other war zones. ${ }^{43}$ The works of Mohammed Al-Zumur ${ }^{44}$ illustrate this intention: the artist collects ammunitions from the war, hangs nationalist Arab poems on them, and turns them into art installations, in order to "deliver a message of peace and love amidst destruction"45 [Fig. 5]. While all these artists are driven by the same need to provide an alternative image of Gaza, their productions remain hybrid and experimental, torn between a style marked by strong local influences and an increasingly popular attraction towards contemporary art (in this case installation art).

Furthermore, in this local context, the increasing use of new technologies by this generation of artists offers another response to their imprisonment. To overcome constraints, digital technologies provide an effective means for producing and sharing artistic creations during wartime. During the summer 2014 war, digital art was extremely popular on social media: Belal Khaled (born in 1991), Tawfiq Jebreel (born in 1987) plus a good number of other artists diverted media images, turning the smoke created by Gaza bombings into human and figurative forms [Fig. 6]. This artistic language has recently spread to Gaza and the West Bank, in response to the need (in the artist's own words) to "augment reality", "transmit the human image of conflict" and "give a gleam of hope, peace and life" amidst a context of crisis. What would later be called "smoking art" was born out of a feeling of urgency and hastily carried out in the midst of war - at times when the electricity was turned on ${ }^{46}$ - before being shared on social media and widely covered by the international press.

Digital technology has also given rise to practices that have become very fashionable among young artists: inherited from political posters

(a

favourite

\footnotetext{
38 Statement by the artist, appearing in the exhibition catalogue (personal archives).

39 Tawil-Souri, Helga, Gaza as metaphor, Hurst \& Company London, London, 2016, p. 16

40 Florida, Richard, Cities and the Creative Class, Routledge, 2005.

41 I am referring here to Cynthia Ghorra-Gobin, "L'espace public: entre privatisation et patrimonialisation", Revue Esprit, Editions Esprit, 2012, pp.88-98 and Levy J., Lussault J. (dir.), Logiques de l'espace, esprit des lieux. Géographies à Cerisy, Belin, Paris, 2000.

42 Rancière, Jacques, Malaise dans l'esthétique, Paris, Galilée, 2004, p. 65.

43 See the catalogue of the exhibition entitled L'Art en guerre. France 1938-1947, from 12 October 2012 to 17 February 2013 at the Paris Museum of Modern Art.

44 Born in 1981 in the Al-Bureij Refugee Camp, Mohammed Al-Zumur did not receive any formal art training but notes that as a child, he loved drawing and creating crafts from materials like wood and iron. For the time being, the shaded porch of his home serves as an exhibition space for friends and journalists interested in viewing his artwork.

45 Interview with Mohammed Al-Zumur, Gaza, September 2014.

46 Gaza residents, $70 \%$ of whom refugees, only had access to between 6 and $16 \mathrm{~h}$ of electricity a day in 2014 . According to the UN, only $10 \%$ of residents have access to water for 6 to $16 \mathrm{~h}$ a day. $70 \%$ of the population was living below the poverty line in 2015 .
} 


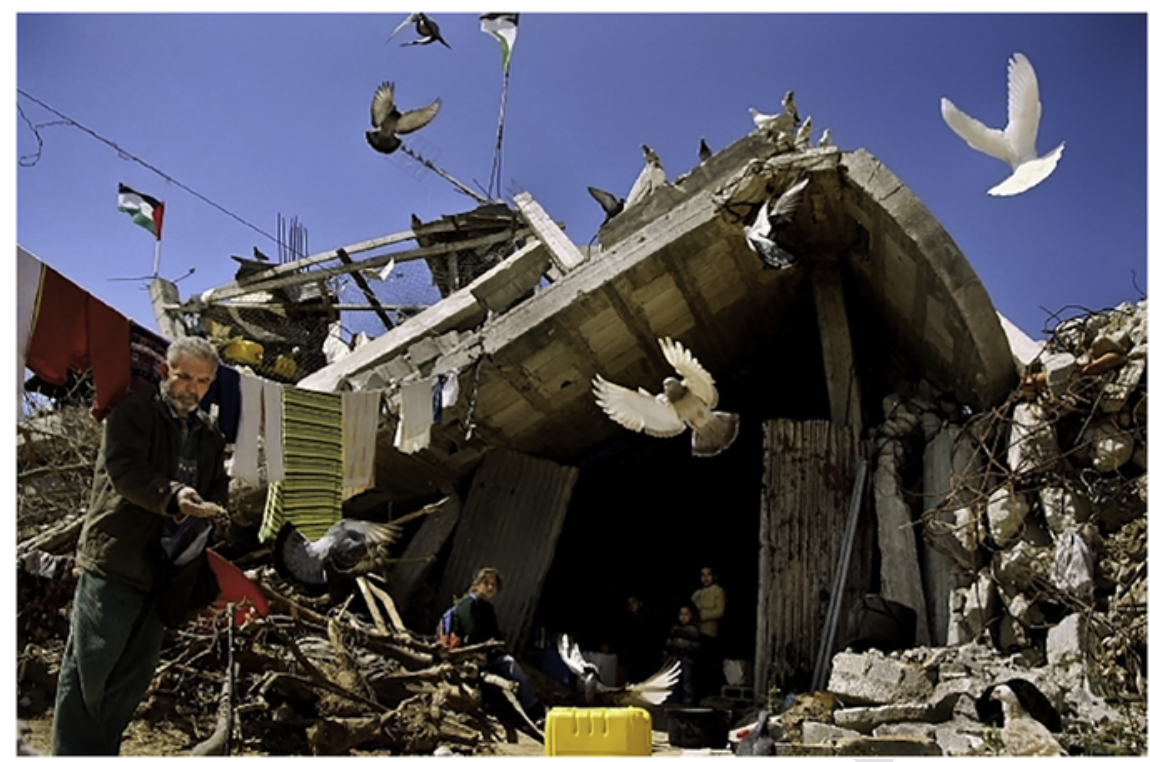

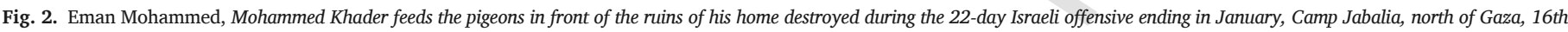
March 2009, Photography, 2009, British Museum Collection, London, (C) Courtesy of the artist

pictorial tradition for the pioneers of Palestinian $\operatorname{art}^{47}$ ), "war postering" flooded Facebook profiles as events unfolded: anti-war, anti-occupation messages, calls for peace, for life, etc. A profusion of posters were created to make their authors' voices heard to the world. A few days after the outbreak of war, on July 8th, a poster went viral: Visit Gaza [Fig. 7] by the twins Arab and Tarzan Nasser, revisiting the famous Visit Palestine by graphic designer Franz Kraus (1905-1998). In relying on black humour, the Dome of the Rock is replaced by the Israeli bombardment of Gaza. The choice of digital technology in artistic practices thus allows overcoming limitations in circulation, helping facilitate the diffusion of art outside of conventional time and space.

Moreover, the fragmentation of the Palestinians and their systematized confinement by the occupation have for a long time fostered development of the Internet and social media in Palestine. These new practices differentiate contemporary artists from their older peers. For this reason, I postulate that a new generation of "post-Oslo"- as in Jîl Oslo ${ }^{48}$ - artists has emerged with the rise of contemporary art in Gaza (and more generally across Palestine). The new artistic practices described above (e.g. war postering, use of new technologies, public spaces) are the fruit of a generation coming of age after the September 1993 agreements. The reference here is to Michel Winock's approach that considers the triggering event and the rallying of an entire generation mark the moment when the group emerges in the public sphere. ${ }^{49}$ This event in the case of Gaza is the four Israeli assaults on Gaza since 2006 that have transformed this generation of Gazans into a "wartime generation", with common artistic practices in times of crisis and common forms of engagement, as is the case elsewhere in the Arab region amidst crisis and protest. ${ }^{50}$

\footnotetext{
47 Many artists of this period produced political posters: www.palestineposterproject org. See also Maasri, Zeina, Off the Wall, Political posters of the Lebanese Civil War, London, New York, IB Tauris, 2009.

48 Maira, Sunaina, Jil Oslo: Palestinian Hip Hop, Youth Culture, and the Youth Movement, Tadween Publishing, Washington, 2013.

49 Winock, Michel, "Les générations intellectuelles", in Vingtième Siècle, revue d'histoire, issue No. 22, April-June 1989, pp. 17-38.

50 I am referring here to the work of Cécile Boëx for the cinematographic creation after 2011 in Syria or Anahi Alviso for the visual arts in Yemen: Cécile Boëx, "La création cinématographique en Syrie à la lumière du mouvement de révolte: Nouvelles pratiques, nouveaux récits", Revue des mondes musulmans et de la Méditerranée [Web publication], No. 134, December 2013; Alviso-Marino, Anahi. "Soutenir la mobilisation politique par l'image. Photographie contestataire au Yémen", Participations, Vol. 7, No. 3, 2013, pp. $47-71$
}

4. New forms of engagement and the fabrication of an alternative image of the city

At a time of political stagnation, artists strive to "change the world" through their creations in a utopian manner. "Beyond exposing our life in Gaza, it's all about sending the message to Israel that despite its efforts to destroy the Palestinian people, artists will not shut up", ${ }^{51}$ explains Belal Khaled, the author of the aforementioned "smoking art" drawings. "It's resistance through art, artistic resistance. The Palestinian artist must show this image of Palestine to the world", he concludes.

Most creators in Gaza consider themselves as "resistance artists" (fannân muqâwim), yet they ascribe to this notion a broader meaning than that adopted by members of former generations' national resistance movements. The iconography of resistance is often depicted in Gazan artistic production, but its interpretation is diverse. The artist Raed Issa ${ }^{52}$ attests to this fact in his canvas The resistant musician [Fig. 8]:

"The resistance fighter is always painted with a face covered by the keffiyeh. But the resistance fighter is not necessarily one who takes to arms. I painted a resistance fighter carrying an oud [a mandolin], because resistance is a plural act.". ${ }^{53}$

Through this reinterpretation of traditional iconographic codes (such as the keffiyeh) and the concept of resistance (muqâwama), the artist has defined his creative act as one of peaceful resistance. In the same spirit, Raed Issa, who saw his home destroyed by an Israeli bomb in summer 2014, claimed to be more concerned at the time with "finding an art studio than a home" [Fig. 9].

For some, the simple act of denouncing wartime violence constitutes an act of resistance. At a time when the peace process has collapsed, with politicians having lost all credibility and one deadly attack following another, the visual arts in Gaza illustrate what French philosopher Gilles Deleuze described as an act of creation. For Deleuze, a basic affinity actually exists between artwork and the act of resistance because "only an act of resistance can resist death, in

\footnotetext{
51 Interview with Belal Khaled, Gaza, September 2014.

52 Raed Issa was born in Gaza in 1975 in the Al-Breij Refugee Camp. Despite receiving no artistic training (he studied Information Technology at the Islamic University in Gaza), he won First Prize in the Young Artist of the Year Award organised by the Qattan Foundation. In 2011, he was awarded a residency at the Cité des Arts in Paris.

53 Interview with Raed Issa, Gaza, September 2014.
} 

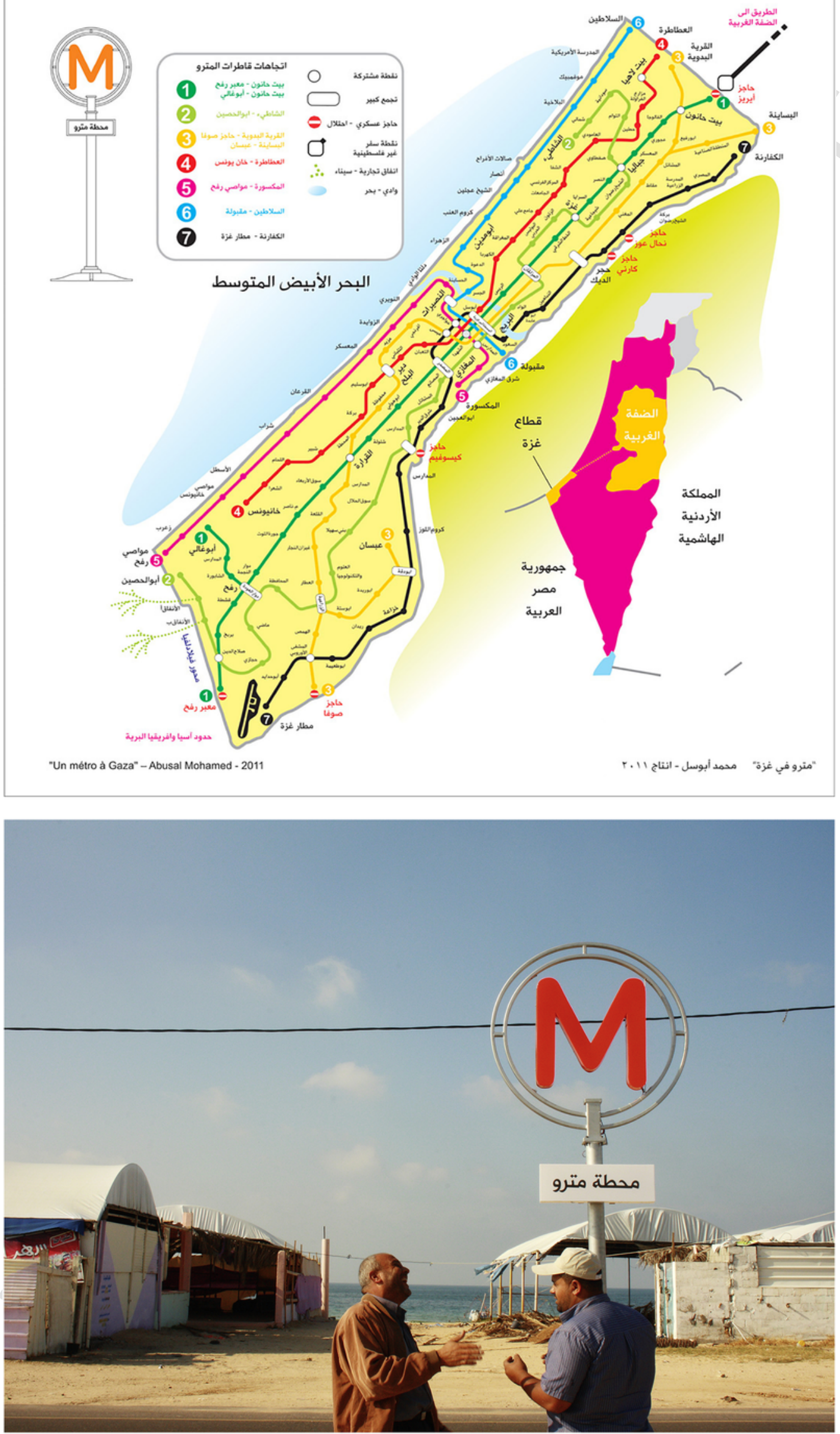

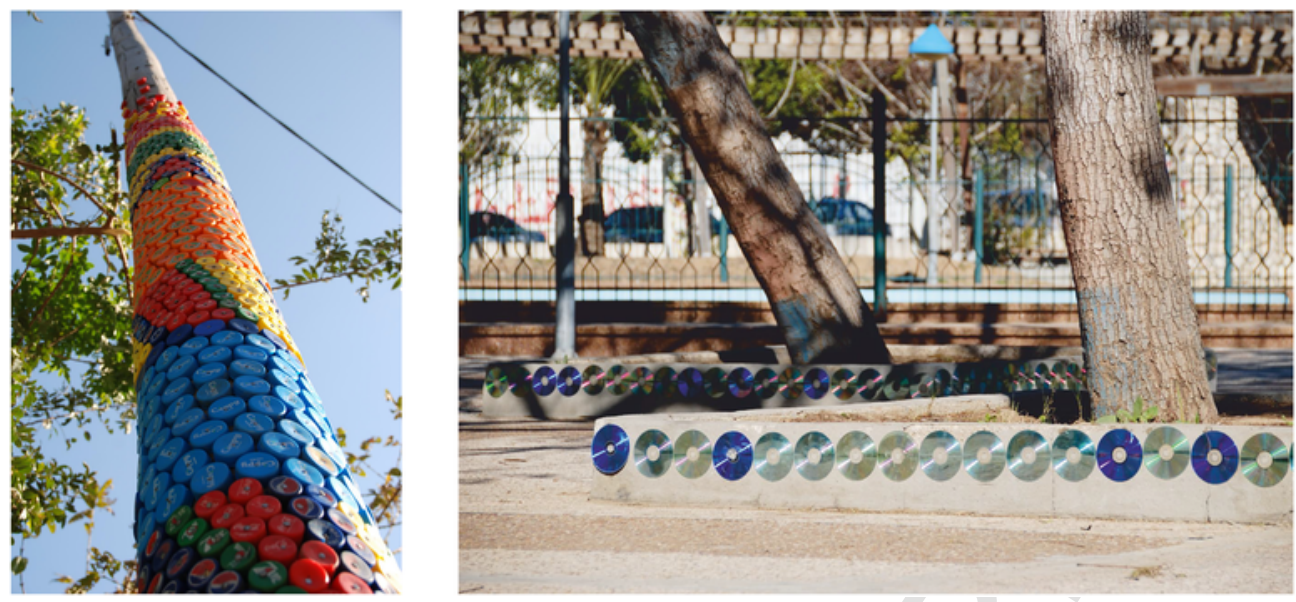

Fig. 4. Mohammed Musallam, Art in public space, Mix media/Urban art, 2013 @ C Courtesy of the artist.

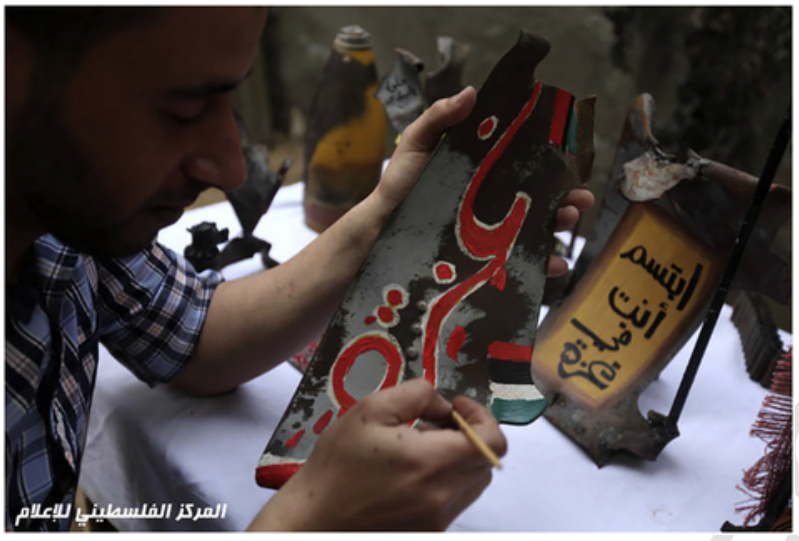

Fig. 5. The artist Mohammed Al-Zumur in his home, which also serves as his art studio, Al-Breij Refugee Camp, 2012, (c) Al-Markaz Al-Falistini Lil-A'lam.

the form of either artwork or a human struggle". ${ }^{54}$ Such is the case for Mohammed Hawajri, ${ }^{55}$ in his work entitled Guernica Gaza 2010-2013 [Fig. 10]. In this work, he reinterprets some great classical paintings of Western art, in introducing elements from his local context (Israeli army, separation wall, arbitrary detentions, etc.) and inserting them surreptitiously into the canvasses of great masters, ranging from Pablo Picasso to Marc Chagall (1887-1985) and Van Gogh (1853-1890). In this tragi-comic work, an anti-war and anti-occupation engagement is expressed, and Hawajri strives to state "the importance of art in documenting reality and historical facts" and to show that "art can influence human behaviour... and reject violence". ${ }^{56}$ Here, the artist is both a witness and a critic of war, a historian-ethnographer of his own time.

Over the past few years, we have witnessed the emergence of a "critical art" 57 addressed not only outwards (often towards Israel), but also inwards towards Palestinian authorities and Gazan society. Echoing the collective mobilisations that took place at the dawn of the Arab uprisings and following the ex-

\footnotetext{
54 Deleuze, Gilles, Deux régimes de fous, Editions de Minuit, Paris, 2003.

55 Born in Gaza in 1976, Hawajri is a self-taught artist who co-founded both the Red Cross's Fine Arts program and the Eltiqa Gallery in Gaza. His works have been exhibited abroad at the Institut du Monde Arabe (Paris), the Darat Al-Funun (Amman), the Ecole Cantonale d'Art at Valais (Switzerland), and the Casoria Contemporary Art Museum in Naples. He has been awarded residencies in Amman (Darat Al-Funun) and Paris (Cité Internationale des Arts).

56 Interview with Mohammed Hawajri, Gaza, September 2014

57 Rancière, Jacques, Le spectateur émancipé, Editions La Fabrique, Paris, 2008, p. 54.
}

ample of "Gaza Youth Break Out", 58 many artists (most of whom participated in these movements) turned their critique directly towards the political factions in power, calling for reconciliation between Fatah and Hamas. Among female artists, one can likewise find the origins of a feminist critique of the patriarchal society they experience.

While continuing to represent their revolt as an act of resistance, this generation of artists wants to ascribe it a new meaning (and, more generally, ascribe a new meaning to politics as well). Faced with a political vacuum and their disenchantment with political factions, young artists and the great majority of Palestinian youth tend to distance themselves from collective forms of engagement. Nationalist rhetoric unites these artists less today than the unveiling of their individual world. This observation does not necessarily mean that artists are no longer producing politicized art, but instead that they are seeing beyond the traditional nationalist frame. Such is what young artist Nidaa Badwan ${ }^{59}$ expresses through photography [Fig. 11]. She plunges the viewer into the heart of her intimate universe, into the daily life of a woman without a face, thus conferring a universal character to her work. Badwan finds strength by distancing herself from depictions of local violence in order to propose, with humour and poetic charm, an alternative way of looking at existence: "I want to give back its colours to Gaza, which knows neither colours nor peace", ${ }^{60}$ she declared after a month of war during summer 2014. In a context of extreme violence, art acts as a form of catharsis. It becomes a way to re-appropriate one's own freedom, with the artwork becoming a symbol of humanity at a time when humanity is being lost.

Across different national and stylistic framings, this new generation of artists intends to embrace a human, perhaps even humanist, cause. Beyond all partisan positions, these young creators seek to incite individual ethical or humanitarian reflection, rather than expressing the political discourse inscribed in the national movement. While Gazan artists evolve in a context that often tends towards the absurd, they themselves are on a quest for normality while other artists, elsewhere in the world, are in search of "reasons" to defend their art. The slogan of the group "Gaza Youth Break Out" as the Arab revolts were erupting, on February 11th 2011, was: "We want to be free, we want to be able

\footnotetext{
58 Youth from the group Gaza Youth Break Out (GYBO) launched a call to protest on February 11th 2011, expressing their despair towards Palestinian representatives, both in Israel and at the international level: "Screw Hamas. Screw Israel. Screw Fatah. Screw the UN and UNRWA. Screw the United States! We, the youth of Gaza, are fed up with Israel, Hamas, the occupation, the permanent violations of human rights and the indifference of the international community."

59 Born in Abu Dhabi in 1987, Nidaa Badwan moved to Gaza in 1998. After graduating from the Fine Arts Department at Al-Aqsa University, she worked as an instructor of plastic arts, artistic expression and photography at the Tamer Institute for Community Education in Gaza between 2009 and 2012. She has lived in San Marino since 2015.
}

60 Interview with Nidaa Badwan, Gaza, September 2014. 


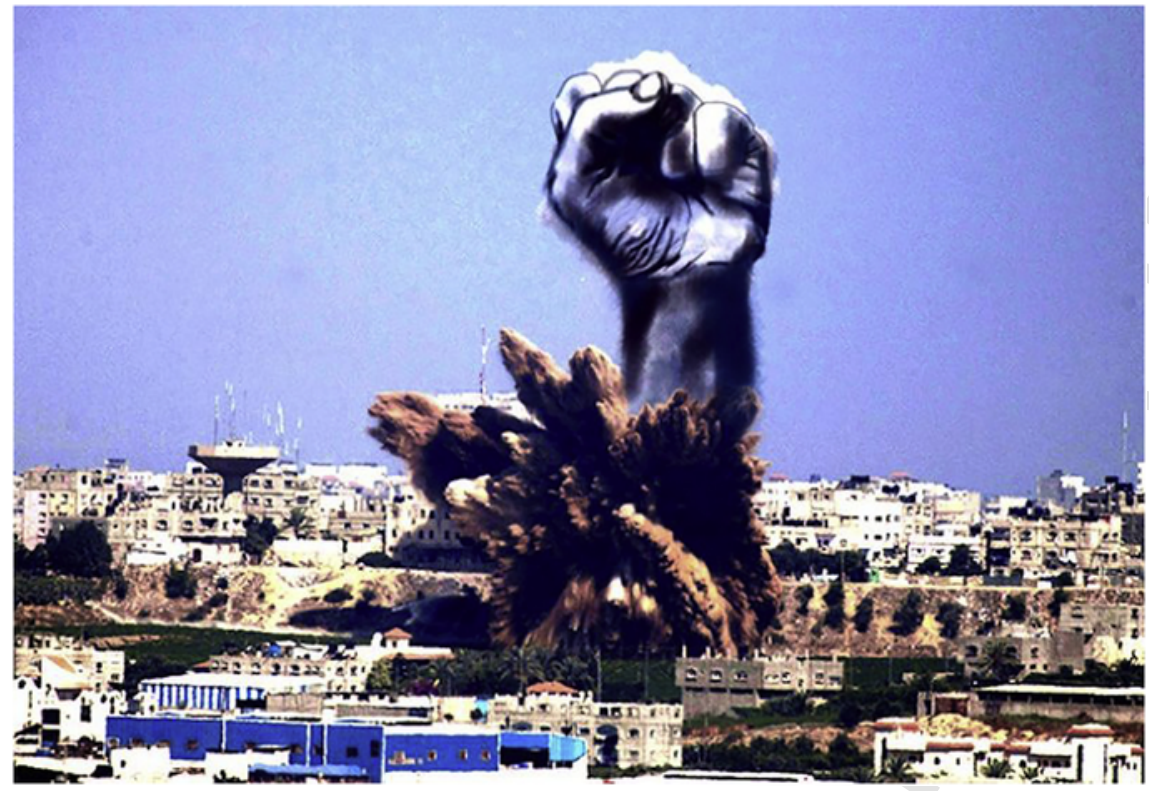

Fig. 6. Belal Khaled and Tawfiq Jebreel, Smoking art, Gaza, 2014, ( Courtesy of the artists.

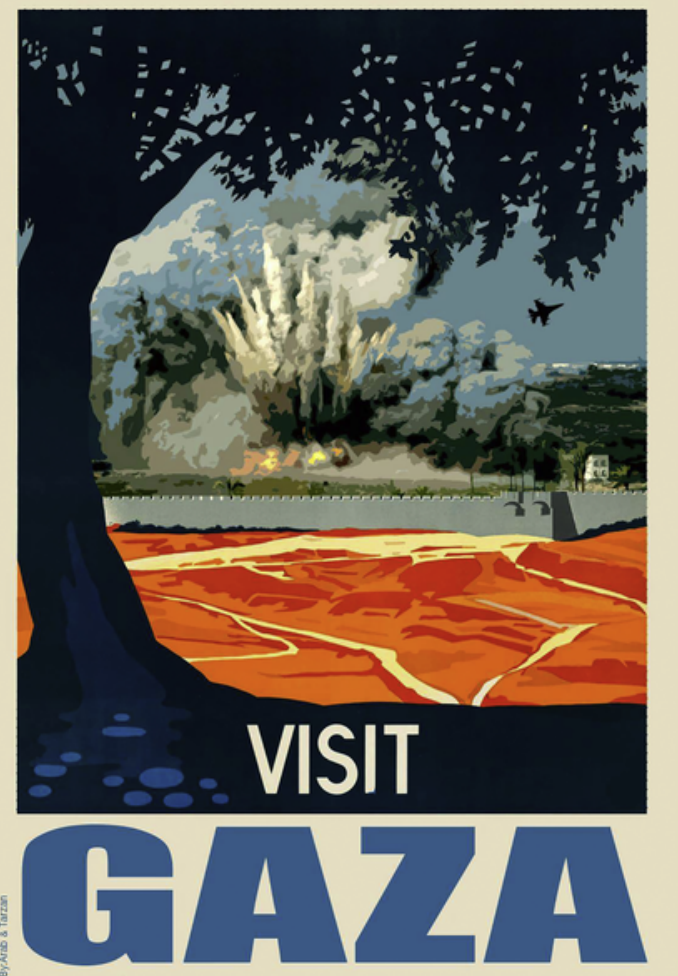

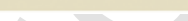

Fig. 7. Arab and Tarzan Nasser, Visit Gaza, Digital Poster, 2014 (inspired by Visit Palestine poster, by Franz Kraus, on the right), (C) Courtesy of the artists.

to live normally and we want peace". What emerges with this young generation of artists is a social criticism of the traditional "top-down" institutions and of the representatives holding power.

Against this backdrop of a rupture with conventional political processes, the artist's engagement is moving from purely nationalist art towards universalism, whereby art is considered as a struggle for human rights. This transition was brilliantly illustrated at the latest Gaza film festival, "Karama Gaza Red Carpet Human Rights Film Festival" [Fig. 12], launched by film director Khalil

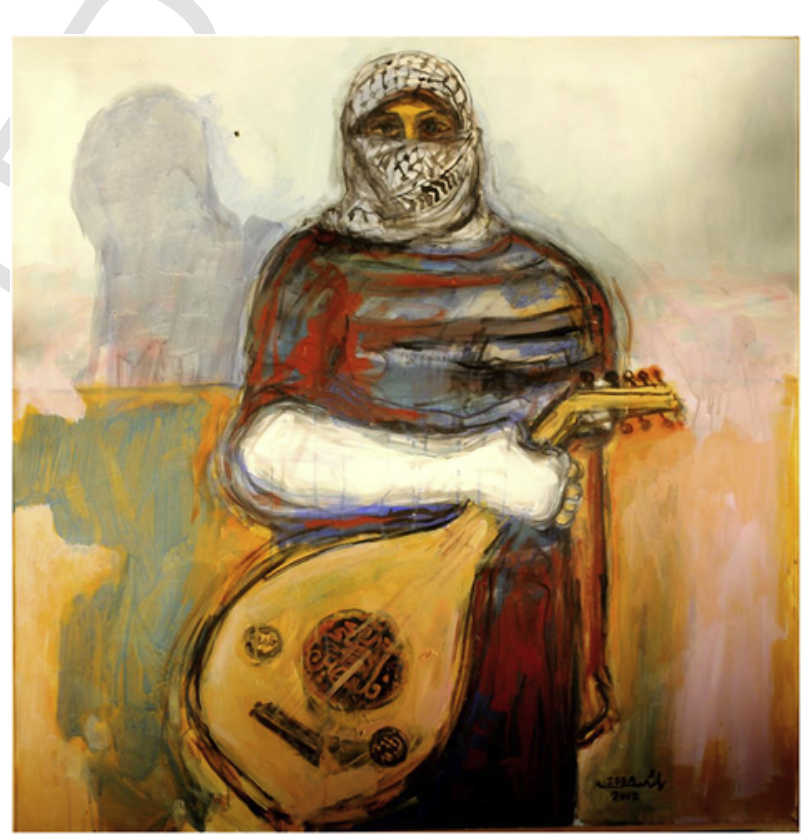

Fig. 8. Raed Issa, The musician fighter, Oil on canvas, 2010, ( Courtesy of the artist.

Mozaien ${ }^{61}$ in May 2015 following Israel's offensive on Gaza and simultaneously with the more glamorous Cannes Festival in France. The first edition entailed organising the festival amidst the ruins of Shuja'iye, which had been completely bombarded during Israel's 2014 offensive on Gaza. The organisers unfurled a long red carpet between the destroyed houses, and thousands of people attended open-air screenings, most of them for the first time in their lives since Gaza had no cinema halls. This is a great example of artist and citizen initiatives originating in civil society and creatively transforming environmental constraints into advantages. The festival trailer went viral on social media, and the festival received widespread international press coverage with the or-

61 Born in Gaza, Khalil Mozaien is a Palestinian documentary and feature filmmaker. After completing a doctorate degree in cinema studies in St Petersburg, he has produced numerous films, including Mashoo Matook, which screened at the Cannes Film Festival in 2010. He has lived in Canada since 2016. 


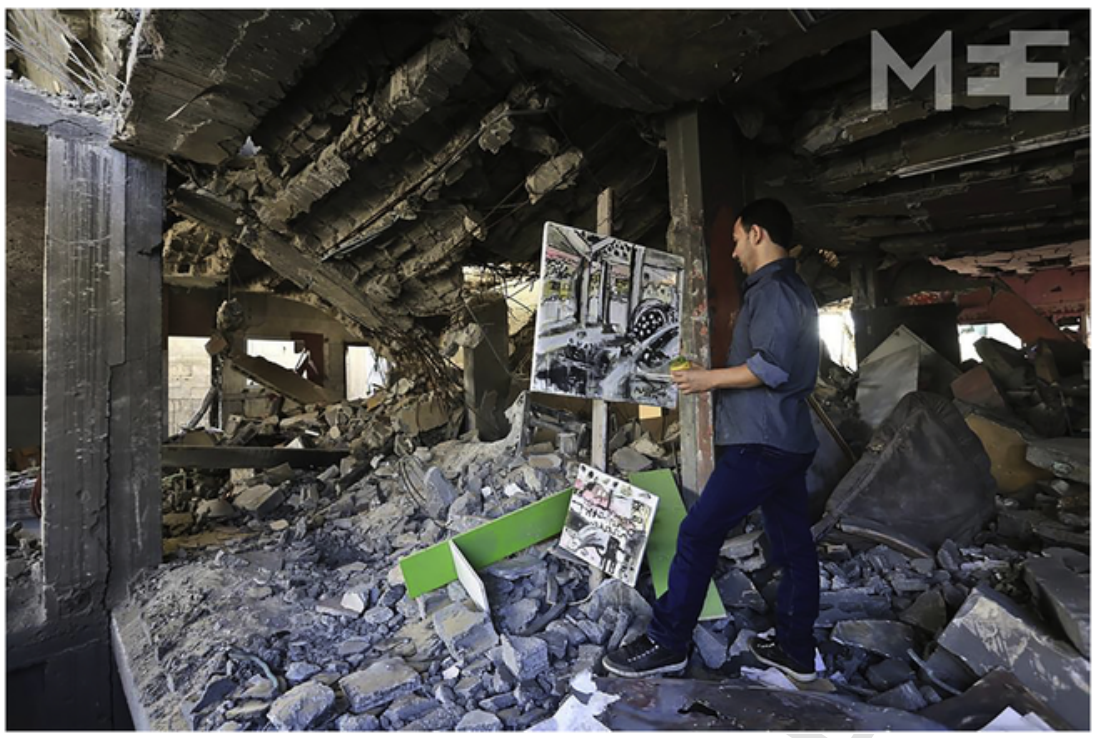

Fig. 9. The artist Raed Issa painting in the ruins of his destroyed house after the Gaza war of summer 2014, ( $)$ Anne Paq.

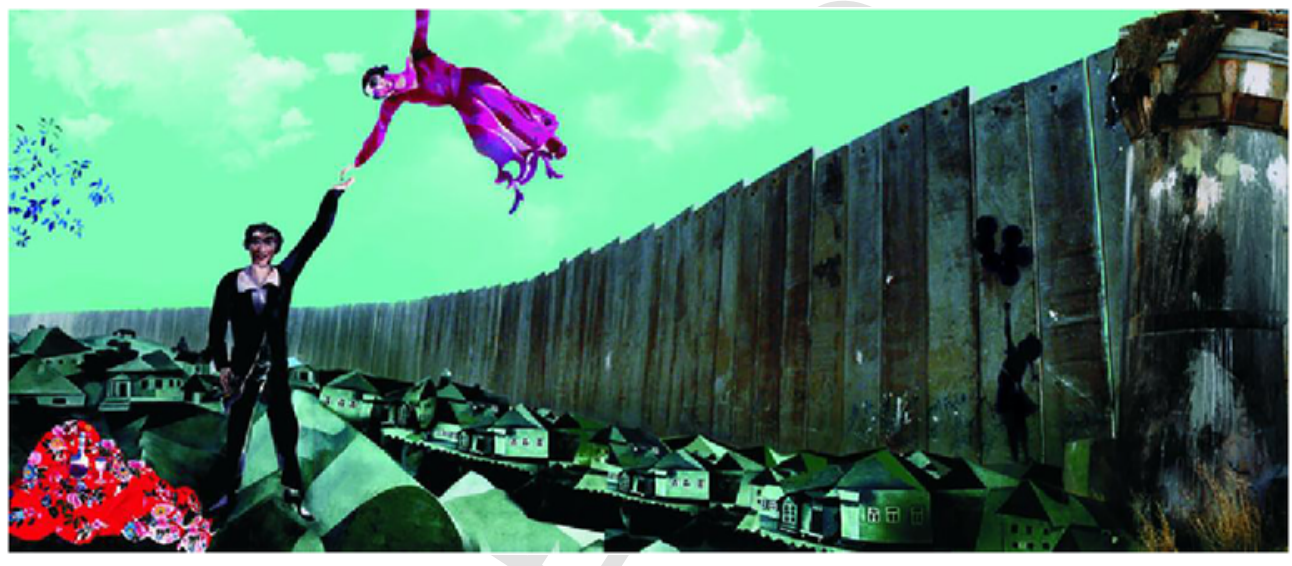

Fig. 10. Mohammed Hawajri, Guernica Gaza, Digital art, 2010, (c) Courtesy of the artist

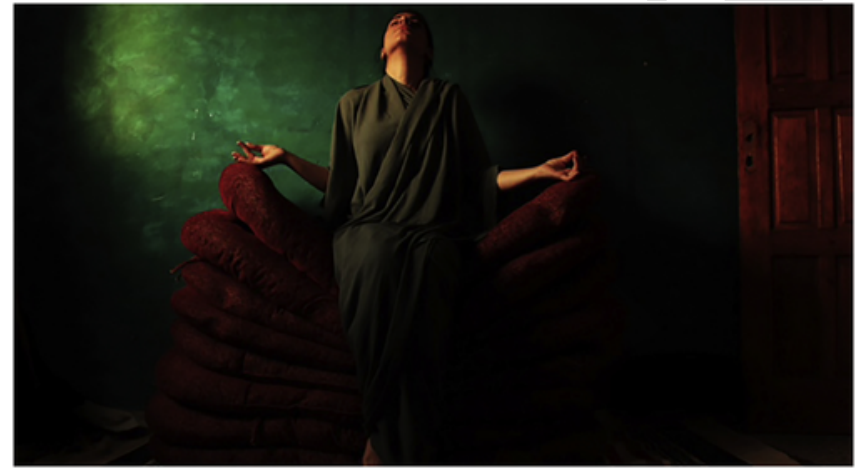

Fig. 11. Nidaa Badwan, One Hundred Years of Solitude, Photography, 2014, @ Courtesy of the artist.

ganisers' motto being often repeated: "we want to live, we want to breathe". In May 2017, the third edition of the festival was held in the Gaza harbour, after bitter negotiations with the Hamas government finally allowed a hip-hop concert to take place in the public space. This acquiescence is extremely rare in Gaza, as Hamas considers such music to be "pornographic". The tremendous feedback from this event served to reaffirm Gaza's central role in Palestine and moreover denoted a transformation of the marginalized image towards the centre: Gaza's image had shifted, at least symbolically, from a status of marginality to centrality thanks to artistic intervention in the public space. Such artistic practices generate a sense of "cultural empowerment" 62 among local populations and impact visual representation among the international audience, providing an alternative narrative of the city based on its steadfast creativity, its unrelenting resistance and its "will to survive". ${ }^{63}$

According to French philosopher Laurent Gervereau: "Art is made to cling to time, encourage life, challenge oblivion, anonymity, and death". Hence: "[These productions] constitute, in the middle of this universe removed from the world, beyond the world's rules and beyond time [...], a breath, the transmission of hope, a way to do something, to take a distance, moved by the will, the expression of an obsession: to survive". ${ }^{64}$ Here Gervereau is describing the conditions of artistic creation carried out in wartime or imprisonment. His analysis applies to the Second World War, yet despite the many differences, it could also easily apply to Gaza. That which is invented in this exceptional context connected to war is, after all, an art of urgency, raw and experimental, even if ephemeral...

62 Makhoul, Bashir and Hon, Gordon, The Origins of Palestinian Art, Liverpool University Press, Liverpool, 2013.

63 Dabbagh, Selma, "Inventing Gaza", in Tawil-Souri, Helga \& Matar, Dina (dir.), Gaza as metaphor, Hurst \& Company London, London, 2016, p. 132.

64 Gervereau, Laurent, Les images qui mentent, Histoire du visuel au XXe siècle, Seuil, Paris, 2000, p. 213. 


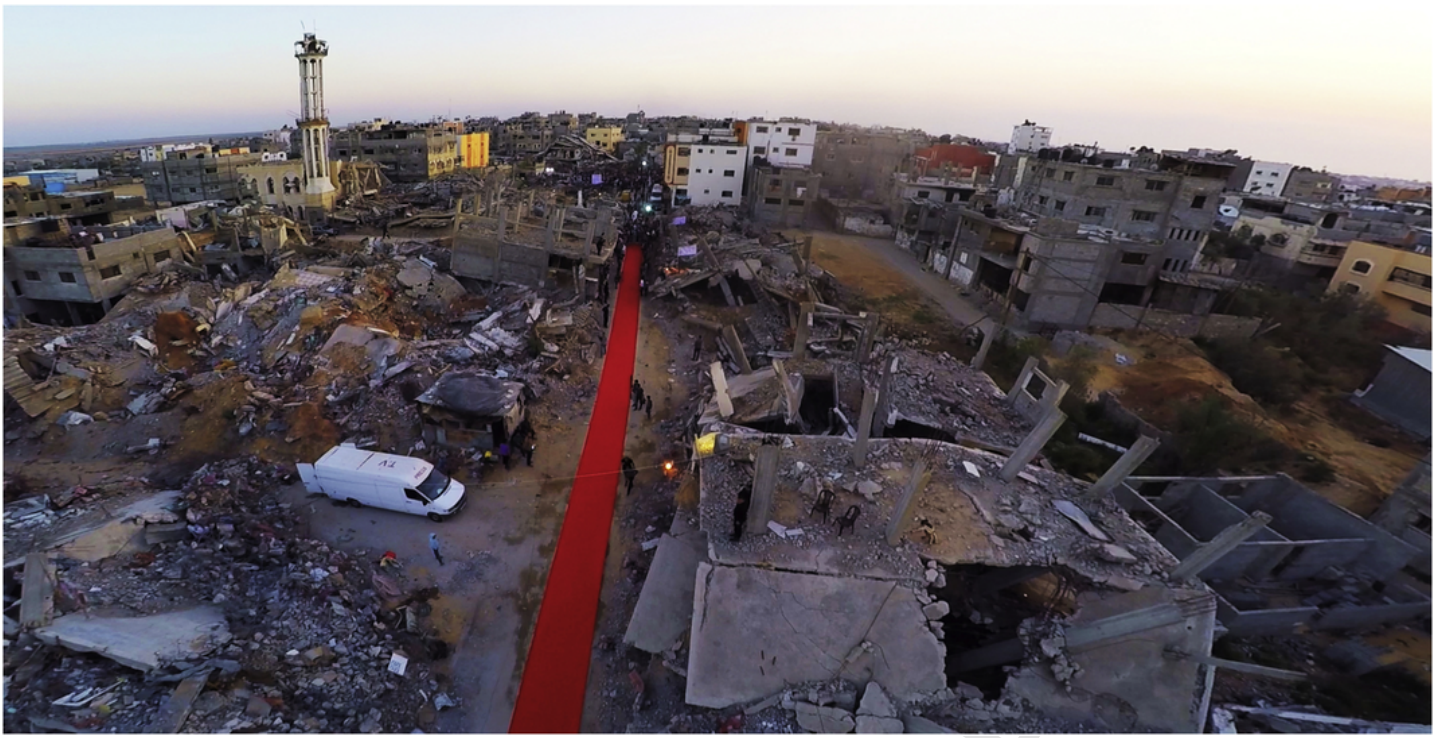

Fig. 12. Khalil Mozaien (Lama Studios), Gaza Red Carpet Film Festival, 2015, (๑ Courtesy of the artist.

\section{Conclusion}

Beyond the impact of artistic intervention on the image of the urban fabric, my analysis leads to concluding that the Gaza Strip proves, paradoxically, to be well adapted to the exercise of contemporary art practices: "In a context of confinement and strong social and economic constraints, this artistic dynamic articulates local and global dimensions, translating openings on other physical and symbolical spaces which are the counterpart of confinement". ${ }^{65}$ The fragility of contemporary art in Gaza, which lacks stable public or private support networks or a well-established local art market, also endows it with flexibility, a fragmented nature, and an openness to the outside world that are entirely in keeping with the internationalist and nomadic character of contemporary art. Such is the case herein because while the artists of the Palestinian Diaspora work in continuous interaction with their environments, those left behind in Palestine and Gaza, in particular, have developed self-sustaining practices tied to their living conditions and marked by an absence of freedom, economic insecurity and dramatic political changes. Under such conditions of confinement, artistic development occurs through breaks with the past and reinvention rather than through accumulation and imitation as a way of expressing freedom and resistance. ${ }^{66}$ As Edgar Morin reminds us, "a crisis both reveals and enacts: it has an aspect of awakening about it, one that in theory instructs us about possibilities both for surviving and for transforming a crisis situation". ${ }^{67}$ The case of contemporary art in Gaza is a striking example of a crisis situation that does not necessarily lead to a break or a disturbance, but one that reveals the creativity of a society as a whole. It is precisely this situation of crisis that explains the artistic dynamism of this "prison breeding ground" of Gaza. However, if new art forms, based on the war context, emerge and oppose marginalization, might one ask, as Arnaud Chabrol did for contemporary Lebanese artists after that country's Civil War, if the danger exists for Gazan

65 Puig, Nicolas, “Shi filastini, quelque chose de palestinien'. Musiques et musiciens palestiniens au Liban: Territoires, scénographies et identités” [Shi Filastini, Something Palestinian. Palestinian Music and Musicians in Lebanon: Territories, Venues and Identities], Tumultes, No. 27, 2006/2, pp. 109-134.

66 See also art dynamism in border zones, encouraging artists towards forms that bypass borders, as Anne-Laure Amilhat Szary describes it in her works: Anne-Laure Amilhat Szary, Marie-Christine Fourny. "L'art aux limites nationales. Petite lecture géopolitique et géosymbolique des productions artistiques des frontiers", in Mirmanda, Revista de cultura, Revue de culture, Catalonia, 2010, p. 100; "L'artiste passe-muraille?", EspacesTemps.net, Travaux, 19.11.2013, p. 16

67 Morin, Edgar, "Pour une crisologie", in Communications, 25, 1976, pp. 149-163. artists to become "war prisoners", ${ }^{68}$ condemned to be categorized within the "Occidental laboratory" of cultural agents as an oriental, an Arab or a Palestinian artist rather than simply an artist.

\section{Uncited references}

Boex, 2013

Filiu, 2015

Grondhal, 2009

Matar and Tawil-Souri, 2016

Ranciere, 2004

Ranciere, 2008

\section{References}

Alviso-Marino, A., 2013. Soutenir la mobilisation politique par l'image. Photographie contestataire au Yémen. Participations 7 (3), 47-71.

Amilhat-Szary, A.-L., Fourny, M.-C., 2010. L'art aux limites nationales. Petite lecture géopolitique et géosymbolique des productions artistiques des frontières. In: Mirmanda, Revista de cultura, Revue de culture, Catalogne. p. 100, (AMILHAT-SZARY Anne-Laure, "L'artiste passe-muraille ?", EspacesTemps.net, Travaux, November 2013, p. 16.).

Boex, C., 2013, Décembre. La création cinématographique en Syrie à la lumière du mouvement de révolte: nouvelles pratiques, nouveaux récits. In: Revue des mondes musulmans et de la Méditerranée. 134

K.. ,

Chabrol, A., 2010. La fabrique artistique de la mémoire : effet de génération et entreprises artistiques dans le Liban contemporain. In: Mermier, F., Varin, C. (Eds.), Mémoires de guerres au Liban (1975-1990), Sindbad/Actes Sud/Ifpo, pp. 485-509.

Deleuze, G., 2003. Deux régimes de fous. Editions de Minuit, Paris.

Filiu, J.-P., 2015. Histoire de Gaza. Pluriel, Paris.

Florida, R., 2005. Cities and the creative class. Routledge.

Gervereau, L., 2000. Les images qui mentent, Histoire du visuel au XXe siècle. Seuil, Paris.

Ghorra-Gobin, C., 2012. L'espace public: entre privatisation et patrimonialisation. In: Revue Esprit. Editions Esprit, pp. 88-98.

Ghoul, A., 2013, February 6. The death of the cinema in Gaza. In: Al-Monitor.

Graham, S., 2007, January. Introduction to urbicide: The killing of cities?. In: Theory \& event.

Grondhal, M., 2009. Gaza graffiti: Messages of love and politics. The American University in Cairo Press, Cairo.

S.

Lambert, L., 2013. Weaponized architecture: The impossibility of innocence. DPR-Barcelona, Barcelona, Spain.

Legrain, J.-F., 2009. Hamas et Fatah dans leur rivalité médiatique. In: Confluences Méditerranée. Vol. 2, no.69, pp. 75-86.

2000. Logiques de l'espace, esprit des lieux. In: Levy, J., Lussault, J. (Eds.), Géographies à Cerisy. Belin, Paris.

68 Chabrol, Arnaud, "La fabrique artistique de la mémoire: effet de génération et entreprises artistiques dans le Liban contemporain", in Mermier, Franck and Varin, Christophe (dir.). Mémoires de guerres au Liban (1975-1990), Sindbad/Actes Sud/Ifpo, 2010, pp. 508. 
Lextrait, F., Kahn, F. (Eds.), 2005. Nouveaux territoires de l'art. Montreuil, Sujet. Maasri, Z., 2009. Off the wall, political posters of the Lebanese civil war. IB Tauris, London, New York.

Maira, S., 2013. Jil Oslo: Palestinian hip hop, youth culture, and the youth movement, Tadween Publishing, Washington.

Makhoul, B., Hon, G., 2013. The origins of Palestinian art. Liverpool University Press, Liverpool.

Matar, D., Tawil-Souri, H. (Eds.), 2016. Gaza as metaphor. Oxford University Press, Hurst. S.. In: J.

E.., ()

Novosseloff, A., Neisse, F., 2007. Des murs entre les hommes. La Documentation française, Paris.
Puig, N., 2006. "'Shi filastini, quelque chose de palestinien". Musiques et musiciens palestiniens au Liban: territoires, scénographies et identités', Tumultes, no 27. Vol. 2, 109-134.

Ranciere, J., 2004. Malaise dans l'esthétique. Galilée, Paris.

Ranciere, J., 2008. Le spectateur émancipé. Editions La Fabrique, Paris.

I.. ()

Tawil-Souri, H., Matar, D. (Eds.), 2016. Gaza as metaphor. Hurst \& Company London, London.

Winock, M., 1989, Avril-Juin. Les générations intellectuelles. In: Vingtième Siècle, revue d'histoire. pp. 17-38, (no. 22) 